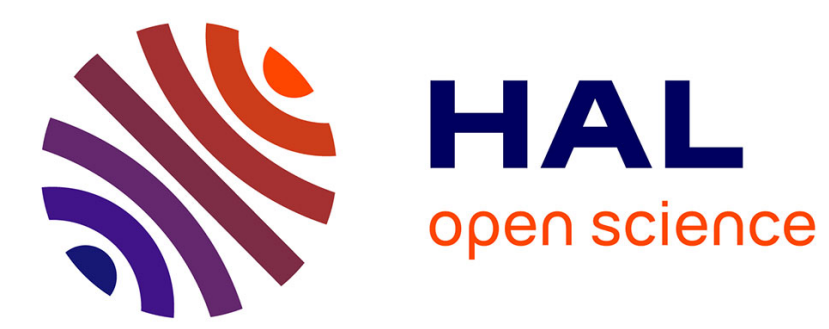

\title{
Are Armenian political elites opening up to think tanks? Vardan Atoyan
}

\section{To cite this version:}

Vardan Atoyan. Are Armenian political elites opening up to think tanks?. 2018. hal-03271665

\section{HAL Id: hal-03271665 \\ https://hal.science/hal-03271665}

Submitted on 26 Jun 2021

HAL is a multi-disciplinary open access archive for the deposit and dissemination of scientific research documents, whether they are published or not. The documents may come from teaching and research institutions in France or abroad, or from public or private research centers.
L'archive ouverte pluridisciplinaire HAL, est destinée au dépôt et à la diffusion de documents scientifiques de niveau recherche, publiés ou non, émanant des établissements d'enseignement et de recherche français ou étrangers, des laboratoires publics ou privés. 


\title{
ARE ARMENIAN POLITICAL ELITES OPENING UP TO THINK TANKS?
}

\begin{abstract}
Author: Vardan Atoyan
Published online: January 10, 2018.

Publisher: On Think Tanks.

Source: <https://onthinktanks.org/articles/are-armenian-political-elites-opening-up-to-think-tanks/>.
\end{abstract}

The formation of the Armenian think tank sector dates from the beginning of 1990s after the independence of the country. In this period, Armenian think tanks faced many challenges and had several stages of evolution.

From the first decade of 2000s with the improvement of the political, social and economic situation in Armenia and the development of democratic institutions, the number of new think tanks founded was in the increase. However, many think tanks didn't last long mainly because of a lack of steady financial resources. Recent research shows that there are currently almost 50 think tanks or think tank-like institutions in Armenia [1].

Only recently, think tanks didn't have enough presence in Armenian political life and sufficient influence on public policy [2]. The primary reason was the inertia of Soviet political culture in which think tanks and other civil society institutions traditionally didn't have enough presence. Some recent developments, however, indicate that this situation is gradually changing. The Armenian political elite is more open to relying on experts' advice and think tanks' intellectual products are greater demand.

A significant step towards involving individual experts and think tanks representatives in consultations and the policymaking process was the establishment of the Analytical Council within the Standing Committee on Foreign Relations of the National Assembly of the Republic of Armenia [3]. The main objective of this Council is to support the National Assembly with different thematic discussions and operative recommendations, which can be used by the parliamentary delegations. The other remarkable step was the signing of a Memorandum between the Standing Committee on Economic Affairs of National Assembly and AMBERD Research Center of the Armenian State University of Economics [4]. According to the above mentioned memorandum AMBERD Research Center became an official scientific adviser-partner of the National Assembly Standing Committee on Economic Affairs. This format of interaction and cooperation of parliament with a nongovernmental think tank is unprecedented in Armenian political culture. 
A third important recent event which is worth mentioning was a meeting and discussion of the President of Armenia with the academic and expert community at Andranik Margaryan Political School, which operates within the ruling Republican Party of Armenia [5].

It is also significant that the revolving door between government and research has seen some progress. Although there were precedents to this: ex-politicians or high level political officials have in the past established their own research centres, the situation until recently was mostly like a oneway road. In November 2017, President Serzh Sargsyan signed a decree appointing Sergey Minasyan Ambassador Extraordinary and Plenipotentiary of Armenia to Romania. Sergey Minasyan, who was at that time deputy director of Caucasus Institute, became the first high-ranked think tanker who was appointed to such kind of high-rank position in government.

It could be assumed that current positive trends in the Armenian think tank sector and the increasing role of think tanks in public policy will continue. The political elite will continue changing its attitude towards them and increase its attention towards experts and knowledge brokers in society.

This increased interest should be evidenced in a growing demand for intellectual products and consultations.

This situation is mainly linked to the political and institutional transformations as well as the security and economic reforms facing Armenia. They demand the development of democratic institutions, the democratisation of the decision making process, and the establishment and formation of think tanks which are able to produce high quality intellectual products and usher a gradual generational change in the political elite.

\section{REFERENCES}

1. Atoyan, V. (2017). Some features of Armenian think tank industry. European Science Review, 34, 87-89.

2. Atoyan, V. (2017). Armenian Think Tanks Influence Aspects on Public Policy. European Journal of Law and Political Sciences, 2, 59-62.

3. National Assembly of the Republic of Armenia 2017, First Meeting of "Analytical Council" Working Group Experts Held, media release, accessed June 13, 2017, $<$ http://parliament.am/news.php?cat_id=2\&NewsID=9265\&year=2017\&month=06\&day=13\&lang= eng>.

4. National Assembly of the Republic of Armenia 2017, Memorandum Signing in RA National Assembly, media release, accessed July 21, 
$<$ http://parliament.am/news.php?cat_id=2\&NewsID=9398\&year=2017\&month=07\&day=21\&lang= eng>.

5. The President of the Republic of Armenia 2017, President hosted at Andranik Margaryan Political School, media release, accessed December 14, 2017, <https://www.president.am/en/pressrelease/item/2017/12/14/President-Serzh-Sargsyan-visited-RPA-political-school/>. 